\title{
Environment reporters and U.S. journalists: A comparative analysis
}

\author{
David B. Sachsman \\ James L. Simon \\ Fairfield University, jsimon@fairfield.edu \\ JoAnn Meyer Valenti
}

Follow this and additional works at: https://digitalcommons.fairfield.edu/english-facultypubs Copyright 2008 Taylor \& Francis

This is an Author's Original Manuscript of an article whose final and definitive form, the Version of Record, has been published in the Applied Environmental Education and Communication: An International Journal, 7(1-2), 1-19 [copyright Taylor \& Francis], available online at: http://www.tandfonline.com/10.1080/15330150802194862.

\section{Repository Citation}

Sachsman, David B.; Simon, James L.; and Valenti, JoAnn Meyer, "Environment reporters and U.S. journalists: A comparative analysis" (2008). English Faculty Publications. 63.

https://digitalcommons.fairfield.edu/english-facultypubs/63

\section{Published Citation}

Sachsman, David B.; Simon, James \& Valenti, JoAnn Myer (2008). "Environment reporters and U.S. journalists: A comparative analysis." Applied Environmental Education and Communication: An International Journal, 7(1-2), 1-19.

This item has been accepted for inclusion in DigitalCommons@Fairfield by an authorized administrator of DigitalCommons@Fairfield. It is brought to you by DigitalCommons@Fairfield with permission from the rightsholder(s) and is protected by copyright and/or related rights. You are free to use this item in any way that is permitted by the copyright and related rights legislation that applies to your use. For other uses, you need to obtain permission from the rights-holder(s) directly, unless additional rights are indicated by a Creative Commons license in the record and/or on the work itself. For more information, please contact digitalcommons@fairfield.edu. 


\title{
Environment Reporters and U.S. Journalists: A Comparative Analysis
}

\author{
David B. Sachsman \\ West Chair of Excellence in Communication and Public Affairs \\ 210 Frist Hall, Dept. 3003 \\ University of Tennessee at Chattanooga \\ 615 McCallie Ave. \\ Chattanooga, TN 37403 \\ David-Sachsman@utc.edu \\ (423) 425-4219, fax (423) 425-2199 \\ James Simon \\ Department of English \\ Fairfield University \\ Fairfield, CT 06430 \\ jsimon@mail.fairfield.edu \\ (203) 254-4000 ext. 2792, fax (203) 254-4131 \\ JoAnn Myer Valenti \\ Emerita Professor \\ 824 South Oregon \\ Tampa, FL 33606 \\ valentijm@yahoo.com \\ (813) 251-5754
}

Authors' Note: The authors' names are listed in alphabetical order; each contributed equally to the study. An earlier version of this research was presented at the $90^{\text {th }}$ annual convention of the Association for Education in Journalism and Mass Communication, Washington D.C., Aug. 9, 2007. Correspondence concerning this article should be addressed to David B. Sachsman, University of Tennessee at Chattanooga, 210 Frist Hall, Department 3003, 615 McCallie Ave., Chattanooga, TN 37403; e-mail: David-Sachsman@utc.edu.

Copyright (C 2008 by David B. Sachsman, James Simon, and JoAnn Myer Valenti. Published with permission 


\begin{abstract}
This study provides baseline data regarding environment reporters in the $21^{\text {st }}$ century, and then compares this baseline information about a specialized journalism beat to existing studies of U.S. journalists in general. This comparison between 652 environmental journalists working at daily newspapers and television stations and more than 1,000 U.S. journalists in general found that these reporters share many individual and work-related characteristics, perhaps due in part to their similar backgrounds and to the basic professional training received by most journalists. The authors propose a uniform theory of journalism education, arguing that journalists are journalists first because they are linked by their studies, training, and experience, and that differences among reporters may be related to variations in their education. The researchers also found that newspapers employ more specialized reporters than do television stations, and that the bigger the newspaper, the more specialists, suggesting that bigger is better for specialized reporting.
\end{abstract}

KEYWORDS: environment; reporters; journalists; newspapers; television; communication; risk 
Environment Reporters and U.S. Journalists: A Comparative Analysis

\section{Introduction}

For more than two decades, research teams headed by David H. Weaver of Indiana University have conducted comprehensive national studies of U.S. journalists every 10 years (Weaver \& Wilhoit, 1986; Weaver \& Wilhoit, 1996; Weaver, et al. 2007). The statistical profiles, each drawn from a sample of more than 1,000 working journalists, offer rich data showing how journalists have changed in terms of demographics, attitudes, and work routines. While the samples were large enough to allow the researchers to generalize about subgroups such as newspaper and television reporters, the samples could not offer insights into specialized subgroups such as beat reporters.

Since 2000, researchers in Tennessee, Connecticut, and Utah have sought to remedy the lack of baseline information about one subgroup of reporters, those covering environmental issues. These journalists provide a vital link between scientists and other experts studying environmental issues and the general public, who want to know about the natural world in which they live (Atwater, Salwen, \& Anderson, 1985; Rogers, 2002). Previously, there had been no major project that looked at the personal characteristics of environment reporters, their attitudes, and their work routines. This study seeks to fill that gap, both by reporting on those characteristics and then comparing them, whenever possible, to the national data generated by the Weaver group. This research provides the baseline data needed for the systematic study of American journalists and specialized reporters.

Our first hypothesis is that environmental journalists are similar to U.S. journalists in many individual and work-related characteristics, perhaps due in part to the similar backgrounds 
and basic professional training of most reporters. Likewise, we hypothesize that differences between environment reporters and U.S. journalists in general may relate to variations in their education. Finally, we propose that the larger the newspaper, the more likely it will be to employ one or more specialized environment reporters, suggesting that bigger is better for specialized reporting. As recently as 2006, the Los Angeles Times employed "more than two dozen" reporters and editors who specialized in "coverage of science, technology, medicine, or the environment," (Hotz, 2006, p. 57) and, like the New York Times, was a poster child for the concept of bigger is better. The question here is whether the same concept holds true for the more typical "large" newspaper, with a circulation of more than 60,000.

\section{The American Journalist and the Environment Reporter}

The first major national survey of American journalists was done by John W. C. Johnstone and associates at the University of Illinois at Chicago. The 1971 survey was published in 1976 as The News People: A Sociological Portrait of American Journalists and Their Work by the University of Illinois Press (Johnstone, Slawski, \& Bowman, 1976). Weaver and G. Cleveland Wilhoit continued this landmark project in 1982-83 and 1992. Their work was published as The American Journalist: A Portrait of U.S. News People and Their Work in 1986 and as The American Journalist in the 1990s: U.S. News People at the End of an Era in 1996. In 2002, Weaver, Randal A. Beam, Bonnie J. Brownlee, Paul S. Voakes and Wilhoit conducted the most recent survey, which was published as The American Journalist in the $21^{\text {st }}$ Century: U.S. News People at the Dawn of a New Millennium (copyright 2007 although it actually came out in 2006).

The 2002 survey, consisting of 97 questions, was completed by 1,149 American journalists working for daily and weekly newspapers, radio and television, news magazines, and 
wire services, "plus additional separate samples of 315 minority and on-line journalists" (p. 255). "The maximum sampling error at the $95 \%$ level of confidence for this main probability sample is plus or minus 3 percentage points" (p. 259). It provides extensive data, including the basic characteristics of U.S. journalists, their education, their media use, their politics, their job satisfaction, and their perceptions of the workplace. The results of the current survey showed some differences from previous findings, including the fact that the average journalist in 2002 was older than in the previous decade. But, overall, the authors concluded, "The picture of U.S. journalists in 2002 " is "one marked more by stability than change" (p. 239). According to the survey, the typical American journalist was Caucasian, male, married, and "just over forty" (p. 1). He was a graduate of a public university who was satisfied with his current employment working for a daily newspaper owned by a large corporation. He either majored in journalism or communication (57.7 percent), English (14.9 percent), or a wide variety of other subjects (p. 44). The physical and biological sciences (including agriculture) were near the bottom of the list with only 2.9 percent.

One might think that reporters assigned to covering a specialized beat like the environment would be more experienced and better educated in their subject areas than the average U.S. journalists described by Weaver. In the 1960s and 1970s, environment reporting often was a province of the science beat (Sachsman, 1973; Storad, 1984). Twenty years later, when the Society of Environmental Journalists was created, environment reporters came with a variety of different backgrounds and environmental stories often were also government stories, science stories, health stories, and even business stories (Ward, 2001). Today, environment reporting tends to be "the chronicling [of] the endless tug of war in politics, economics, and environmental advocacy," says former Atlanta Constitution staff reporter and nature writer 
McKay Jenkins (Blum et al., 2006, p. 229). But science remains fundamental to the environment beat, and so one would hope that environment reporters would differ from other journalists, many of whom apparently spent their college years avoiding science and math (Sachsman, 1985). Morris (1999) questions whether a traditional journalism school education qualifies reporters to write about health and science, arguing that while "new graduates are prepared to cover simple stories that reflect their undergraduate training," they may not be prepared for coverage of more complex issues (p.188). Morris believes that many journalists "take courses in the natural sciences and physical sciences," pointing to "specialized journalism programs sponsored by various foundations at universities across the country" (p. 189). But he concludes that "much more work needs to be done both within journalism and outside."

Are environment reporters better educated in the sciences than other U.S. journalists? Do they go to journalism school or study the sciences? Or some combination of the two? These questions are answered by the current research.

Science writers had been analyzed as early as the 1930s (Krieghbaum, 1940). But while modern environment reporters had been described and discussed since the 1970s (Atwater, Salwen, \& Anderson, 1985; Cantrell, 1993; Cohn, 1990; Friedman, 1990, 2003; Greenberg et al., 1989; Hansen, 1993; Sachsman, 1976, 1996; Taylor, Lee, \& Davie, 2000; Valenti, 1995, 1998), there was no thorough data-based statistical analysis of these specialized professionals. More was known about the sources they used (Greenberg et al., 1989; Lacy \& Coulson, 2000; Sachsman, 1973; Smith, 1993; Taylor, Lee, \& Davie, 2000; Valenti, 1998, 1999, 2000a, 2000b) than about their demographics or feelings. What was missing was precisely the kind of baseline data and description provided by Weaver and Wilhoit for U.S. journalists in general. 
The lack of previous large-scale demographic studies of environment reporters may be due to a stumbling block in such research: there is no definitive list of these reporters. Many belong to the Society of Environmental Journalists; many do not. Some cover the environment as a beat, on a full-time basis. Other self-identified environment reporters spend most of their time covering a variety of issues and switch to the environment when there is breaking news on the topic.

This study used a variety of existing sources to identify environment reporters. The researchers contacted newspapers and television stations, asking to speak to the environment reporter, an editor, or to anyone else who identified themselves as currently working to "cover the environment on a regular basis as part of your reporting duties." The interviewers telephoned every U.S. daily newspaper listed in Editor \& Publisher Yearbook and every television station that had a news director listed in Broadcasting \& Cable Yearbook (thus trying to exclude from the count all those stations that employed no reporters at all). The researchers also excluded those reporters who were assigned to a specific city, town, county, or region and covered all issues - including the environment - pertaining to that community. They excluded those fulltime television weather reporters in small markets who also occasionally handled an environment story such as storm damage, and also reporters who were on leave for medical and professional reasons at the time of the interviews.

The researchers asked environment reporters to identify others at their news organization or at other news outlets who might qualify to be interviewed. The interviewers cast a wide net, seeking to gather information both on specialized beat reporters and those who cover the environment as one of many tasks completed on a given day. The study focused on one region of 
the country at a time, dividing the nation into seven regions ${ }^{1}$ rather than the four regions and nine divisions used by the U.S. Census.

The study began in 2000 in New England, where the researchers identified 55 environment reporters. Each of these reporters completed a forty-five-minute telephone survey interview, resulting in a 100 percent response rate. Interviewers worked their way through the other regions, interviewing 91 of 91 reporters (100 percent) in the Mountain West in 2001; 151 of 158 reporters (95.6 percent) in the South in 2002-03; 116 of 127 reporters (91.3 percent) in the Pacific West in 2002 and 2004-05; 53 of 53 reporters (100 percent) in the Mid Atlantic region in 2003-04; 101 of 117 reporters (86.3 percent) in the Mid Central region in 2004-05; and 85 of 85 reporters (100 percent) in the West Central region in 2004-05. In all, the researchers interviewed 577 of 603 newspaper reporters (95.7 percent) and 75 of 83 television reporters (90.4 percent). There was no evidence that responses varied based on when reporters were interviewed.

Overall, the researchers interviewed 652 of the 686 environment reporters identified, or 95.0 percent. Since the researchers successfully interviewed all but five percent of the subjects they found and since there was no evidence that responses differed due to the year interviewed, it is not unreasonable to treat this research as if it were a national census, rather than a series of regional studies. The results allow the project to report with unusual detail - and without a sampling error - which journalists are environment reporters, where these reporters work, their personal and job-related characteristics, and how they compare to and differ from U.S. journalists in general.

\section{Findings}

Where Are the Environment Reporters? 
Daily newspapers are far more likely than television stations to have an environment reporter. A total of 534 out of 1,462 newspapers (36.5 percent) had at least one environment reporter. This was a much higher percentage than that for television stations, where the study found 86 stations with environment reporters compared to the 859 TV stations with a news director listed in Broadcasting \& Cable Yearbook, or 10.0 percent.

The study also identified news organizations with multiple environment reporters and those that shared reporters. The 534 newspapers with environmental journalists actually employed a total of 603 environment reporters. This included 42 newspapers with two environment reporters, nine newspapers with three, four newspapers with four, and three newspapers with five environment reporters, while 18 newspapers shared eight reporters. Meanwhile, 86 television stations employed a total of 83 environment reporters, including three stations with a total of eight environment reporters and 13 stations sharing five environmental journalists (see Table 1).

\section{Insert Table 1}

The circulation size of the newspapers had a strong correlation with the number of reporters. Of the newspapers with fewer than 14,000 daily circulation, 20.3 percent employed an environment reporter. As circulation increased, so did the likelihood of a newspaper having an environment reporter. Looking at newspapers with more than 60,000 in circulation, 78.7 percent had at least one environment reporter; 17.5 percent had two or more (see Table 2). The bigger the newspaper, the more specialists, suggesting that bigger is better for specialized environmental reporting.

\section{Insert Table 2}


In television, the size of the market may have played a role in determining the presence of an environment reporter at $\mathrm{ABC}, \mathrm{NBC}$, and CBS VHF stations with news directors listed in Broadcasting \& Cable Yearbook. Forty-six of these network affiliated stations in the top 20 television markets had six environment reporters, or 13.0 percent, compared to 10.0 percent for all TV stations identified as having environment reporters.

Regional differences also appear to play a role in determining which newspapers feature environment reporters, as well as how many such journalists are employed. The percentage of newspapers with environment reporters was much higher in the Pacific West (63.3 percent), New England (51.2 percent), and the Mountain West (50.0 percent) than the national average of 36.5 percent. Furthermore, in these three regions, the number of environment reporters was considerably higher than the number of newspapers with environment reporters, meaning many newspapers had more than one environment reporter. Regional differences were less pronounced for television stations than newspapers, with five of the seven regions fairly close to the national average of 10.0 percent. The Pacific West had the highest percentage of TV stations with environment reporters (15.6 percent), as well as the highest percentage of newspapers with such a reporter.

\section{Who Are the Environment Reporters?}

The reporters who cover the environment on a regular basis are pulled from all corners of the newsroom, as shown by their widely varying titles. When the reporters in the study were asked their official job title, fewer than a third (29.0 percent) of the titles included the word "environment" (see Table 3). In addition, a handful of science reporters (1.9 percent of the total), health reporters ( 0.8 percent), and a mixture of natural resource, agriculture, and outdoors reporters (5.6 percent) said they covered environment stories. In contrast, almost half (49.4 
percent) held the title of reporter, general assignment reporter, or staff writer. Another 13.4 percent were beat reporters in other areas (e.g., business, politics, sports) or worked as both an editor and as a reporter. Many said they were assigned environment stories whenever a local story broke that needed coverage, then used any free time for enterprise stories involving the environment.

\section{Insert Table 3}

These job titles also varied across the country. In the South, 39.7 percent of reporters had the word "environment" in their job title, compared to a low of 18.2 percent in New England. Science reporters who covered the environment were most prevalent in New England; those reporters labeled natural resources, agricultural, or outdoors writers were more likely to be found in the Mountain West and the South.

While some of these environment reporters cover the issue full-time, most divide their time, as can be inferred from their job titles. The reporters were asked to estimate how much of their work time they spent, in the previous 12 months, on environment stories. While 26.0 percent said they spent more than two-thirds of their time on environment stories, on average these reporters spent 43.0 percent (mean) of their work week in the previous year on environmental reporting. More than half of the reporters (52.2 percent) spent less than 34 percent of their time on these stories. Again, in the Pacific West and Mountain West, there was more of an emphasis on environment stories. These two regions were the only areas where the average reporter spent 50 percent or more of his or her time on the environment (see Table 4).

\section{Insert Table 4}

In summary, the first part of this study indicates that most newspapers and television stations do not have a reporter covering the environment on a regular basis. Newspapers with 
larger circulations and those in the Pacific West, New England, and the Mountain West were more likely to have an environment reporter than smaller newspapers or those in other regions. And newspapers were much more likely to have a specialist than television stations, even those TV stations in large markets. Reporters who cover the environment on a regular basis have a wide variety of job titles, reflecting the fact that some cover the beat full-time while others juggle environmental issues with other issues of the day.

\section{Comparing Environment Reporters and U.S. Journalists in General}

This study compared environment reporters with U.S. journalists across three dimensions. The first, shown in Tables 5 and 6, includes personal characteristics such as age, ethnicity, gender, religion, and education. Tables 7 and 8 present job characteristics such as perceived level of autonomy and the amount of editing that reporters experience. The third

dimension, detailed in Table 9, looks at media usage patterns such as which newspapers and magazines were read by reporters and how often reporters watched television news.

\section{Personal Characteristics}

\section{Age and experience.}

Weaver et al. (2007) describe a graying of the journalism workforce "as the baby boomers move through the decades" (p. 6). The aging of the workforce can be seen in Table 5, where the percentage of U.S. journalists shifted from ages 25-34 and 35-44 in the 1992 study to a sharp increase of reporters aged 45-54 in 2002. There is a striking similarity in the age groupings of the environment reporters and the U.S. journalists in 2002. Most reporters were spread fairly evenly across the three age groups ranging from age 25 to 54; there was a lower percentage of reporters in the 18-24 age group and in the age 55 and higher group. 
The aging of the workforce also is reflected in the years of experience. Female environment reporters averaged 11.8 years experience, slightly less than female U.S. journalists (13.0 years). Male environment reporters averaged 16.2 years of experience, compared to 18 years for the U.S. journalists. The slightly lower experience level for both male and female environment reporters (compared to U.S. journalists in general in 2002) is surprising, given that beat assignments such as covering the environment are considered prestigious in some newsrooms and frequently go to more experienced journalists. However, there may really be no difference since the national sample survey's "maximum sampling error at the $95 \%$ level of confidence" was "plus or minus 3 percentage points" (p. 259).

\section{Religion.}

The environment reporters were more likely than U.S. journalists to be Protestant, while the U.S. journalists had higher percentages of Catholic and Jewish reporters. A slightly higher percentage of U.S. journalists (36.0 percent) than environment reporters (30.0 percent) said they considered religion to be very important to them, while the percentages saying religion was somewhat important were almost identical.

\section{Ethnicity and gender.}

While both groups were overwhelmingly white, the percentage of white environment reporters was higher (96.6 percent to 91.6 percent). The percentage of males was double that of females in both groups.

\section{Political affiliation.}

Although environmental journalists are sometimes typecast as liberal and pro-Democratic Party in their orientation, the study found the percentage of environment reporters identifying themselves as 
Environment reporters and U.S. journalists 14

Democrats (32.6) was a bit lower than U.S. journalists in 2002 (35.9) and much lower than U.S. journalists in 1992 (44.1). The environment reporters had far more independents (51.8 percent to 32.5 percent), while U.S. journalists in 2002 had almost twice as many Republicans as did the environment reporters (18.0 percent to 9.3 percent).

\section{Insert Table 5}

\section{Income.}

Given the average 14.9 years experience of environment reporters, their reported salary level was very low. Some 47.8 percent said they earned less than $\$ 35,000$ a year; another 40.2 percent said they earned from $\$ 35,000$ to $\$ 60,000$, while the remaining 12 percent earned more than $\$ 60,000$ a year. The U.S. journalists earned a median $\$ 43,588$ in 2002 ; no breakdown by income group was published.

\section{Education.}

The levels of education completed by environment reporters and U.S. journalists in the 2002 survey were very similar. However, there were meaningful differences in terms of undergraduate majors and minors, and probably graduate degrees as well. While the most popular major among both groups was journalism/communication, 23.3 percent of the environment reporters who graduated from college (and answered the question) majored in one or another of the sciences compared to only 2.9 percent of the journalists in general. Furthermore, 38.7 percent of the environment reporters who were college graduates (and answered the question) said they minored in one or another of the sciences. Of the 114 environment reporters who received master's or other advanced degrees, 16 received master's in the sciences. Since a bachelor's degree in the sciences generally is a prerequisite for a graduate 
degree, one can assume that there were very few science master's among the U.S. journalists in general (see Table 6).

\section{Insert Table 6}

\section{Summary: personal characteristics.}

The older workforce employed in journalism by 2002 may have reduced the greater age and experience level one might expect from beat reporters like those covering the environment. In their personal characteristics, similarities outweighed differences. Neither group had the overwhelmingly pro-Democratic party registration that exists in the popular mind. Many of the environment reporters were better educated in the sciences than U.S. journalists in general. Fifty percent of the environment reporters majored in journalism/communication, but many of these minored in a science, and nearly a quarter majored in one of the sciences.

\section{Job Characteristics: Autonomy in the Newsroom}

Specialized reporting slots like covering the environment may be thought to offer the reporter more autonomy in story selection and more independence in handling of stories. Nevertheless, the percentage of environment specialists who said they had "almost complete" autonomy in the newsroom was less than their colleagues among U.S. journalists. For example, when asked whether "they are almost always able to get a story covered that they think should be covered," 52 percent of the U.S. journalists in 2002 responded they had "almost complete" ability to get a story covered, compared to 36.1 percent of the environment writers (see Table 7).

The trend continued across related questions. Forty percent of U.S. journalists said they had almost complete freedom in selecting the stories they work on, compared to 33.1 percent of the environment reporters. Forty-two percent of U.S. journalists said they had "almost complete freedom in deciding which aspects of a news story should be emphasized," compared to 38.2 
percent of environment reporters. When asked about "the amount of editing your stories get from others at your organization," 16 percent of U.S. journalists reported receiving no editing, while only 3.4 percent of environment reporters said they received "none at all."

\section{Insert Table 7}

However, when one measures autonomy by combining those who said they had "almost complete" freedom with those who said they had a "great deal" of freedom, the numbers are more complex. Regarding the amount of freedom men and women had in selecting stories, the percentage of newspaper environment reporters who said they had "almost complete" or a "great deal" of freedom was greater than their male and female counterparts. In television, on the other hand, only female environment reporters said they had more freedom than their counterparts (see Table 8).

\section{Insert Table 8}

\section{Media Usage Patterns}

The environment reporters and U.S. journalists in general shared preferences in the newspapers and magazines they read and the amount of time they spent watching television news. The top four magazines read on a regular basis by environment reporters and U.S. journalists in 2002 were almost the same: Newsweek, Time, National Geographic, and The New Yorker for environment reporters, versus Newsweek, Time, The New Yorker, and Sports Illustrated for U.S. journalists. Not surprisingly, the environment reporters were more likely to read magazines devoted to the natural world, such as National Geographic, Smithsonian, E: The Environment Magazine, and Outside (see Table 9).

The top four newspapers were the same for both groups and reflected the national orientation of all four papers: The New York Times, The Washington Post, The Wall Street 
Journal, and USA Today. The prominence of The New York Times to both groups is worthy of note. The Times was read on a regular basis by almost twice as many U.S. journalists as the second most popular newspaper, The Washington Post. Among environment reporters, The Times was read more than three times as often as the runner-up, again The Washington Post.

The two groups also were similar in not watching conventional evening television network news broadcasts, perhaps in part because they are still working or returning home from work in the early evening. Instead, they were more likely to watch cable TV news, taking advantage of its 24/7 availability. For example, 50.9 percent of environment reporters and 40.4 percent of U.S. journalists (in 2002) said they did not watch any network news broadcasts in an average week. In contrast, 30.4 percent of environment reporters and 16.6 percent of U.S. journalists watched no cable TV news, while 22.7 percent of environment reporters and 23.2 percent of U.S. journalists watched cable news every day.

\section{Insert Table 9}

\section{Job Satisfaction}

Reporters who choose to cover specialized stories like the environment might be expected to report higher levels of job satisfaction than U.S. journalists in general. While this study found high levels of job satisfaction among environment reporters, the levels were similar to those found for U.S. journalists in 2002. Some 85.2 percent of environment reporters said they were very satisfied or satisfied with their jobs, compared to 83.9 percent of U.S. journalists (see Table 10).

\section{Insert Table 10}


The study then broke down job satisfaction by the personal and job characteristics of environment reporters. In doing so, it appears that job satisfaction had a somewhat negative relationship with amount of education. Environment reporters with less than a college degree were more likely to be satisfied than those with more education. There also seemed to be slight differences in job satisfaction related to religious affiliation. But importance of religion correlated with job satisfaction; the more important religion was to environment reporters, the more likely the reporters were to say they were satisfied in their jobs. Environment reporters and U.S. journalists (2002) who were white were very likely to be satisfied with their jobs. And these percentages were almost identical: 85.9 percent and 84.5 percent respectively. However, African-American environment reporters were much more satisfied (100.0 percent) than their U.S. journalist counterparts (77.0 percent). Hispanic environment reporters were less satisfied (66.7 percent) than Hispanic U.S. journalists (78.0 percent). Asian-American reporters in both categories were equally satisfied ( 80.0 percent to 80.9 percent). Men were more satisfied than women both among environment reporters and U.S. journalists, with very similar numbers. Likewise, comparing job satisfaction by age among both categories of reporters showed similar results (see Table 11).

Job satisfaction also correlated highly with job-related characteristics. Television reporters covering the environment were more likely, on average, to report higher levels of job satisfaction than newspaper reporters. Those with an official title including the word "environment" were more likely to be satisfied. The percentage of time covering the environment correlated strongly with job satisfaction; reporters spending at least two thirds of their time on the environment were more likely to be satisfied than those spending less time. 
The study found relationships between job satisfaction and various measures of autonomy. Environment reporters were more likely to be satisfied with their job if they felt their news organizations did a good job of enhancing the public's understanding, if they had freedom in selecting stories and deciding what aspects to emphasize, and if they were free to follow up on a story. The tendency of some reporters to complain about too much editing - and too little editing - is reflected by the results of this study. Reporters who said they received a considerable amount of editing, some editing or little editing were more likely to be satisfied with their job than those whose stories received no editing - or received a great deal of editing.

\section{Insert Table 11}

\section{Discussion}

Research in mass communication requires the systematic accumulation of baseline data. There is a critical need for baseline information from which to develop theoretical work in the future. This need for baseline data is particularly true for comparative journalism research, especially in terms of changes or trends within and between journalistic beats. This study provides such essential baseline data regarding environment reporters, and compares this information to existing studies of U.S. journalists in general. This research tells us where the environment reporters work, who they are, and how they compare to other American journalists.

Daily newspapers are far more likely than television stations to have an environment reporter and newspapers with larger circulations are most likely to have environment reporters and to have more than one environment reporter. Daily newspapers in the Pacific West, New England, and the Mountain West were more likely to have environment reporters than those in other regions. 
Reporters who cover the environment on a regular basis have a wide variety of job titles, reflecting the fact that some cover the beat most of the time while others juggle environmental issues with other issues of the day. Reporters spent, on average, 43.0 percent of their time on environmental stories; the percentage of time rose to 50.0 percent and higher for those in the two most western regions. The environment reporters were journalists first; nearly half were simply called reporters, general assignment reporters, or staff writers.

The older workforce employed in journalism by 2002 may have reduced the greater age and experience level one might expect from beat reporters like those covering the environment. In their personal characteristics, the similarities between environment reporters and U.S. journalists were remarkable. The two groups were particularly similar in age, years in journalism, and gender. And there were more similarities than differences in religion, importance of religion, ethnicity, political affiliation, and education. But while the most popular major among both groups was journalism/communication, many of the students who would go on to become environment reporters did not fit the common stereotype of journalism majors as students who tended to avoid the sciences. The differences between journalists and scientists sometimes are attributed to the assumption that they studied different subjects in college. Although almost all scientists were science majors and half of the environment reporters were journalism or communication majors, many of the environment reporters studied the sciences extensively in college, minoring or even majoring in one or another of the sciences, and 16 of the 114 environment reporters with advanced degrees hold master's in the sciences.

Specialized reporting slots like covering the environment may be thought to offer the reporter more autonomy in story selection and more independence in handling of stories. However, if one defines autonomy as "almost complete" autonomy, then environment reporters 
said they had less autonomy than U.S. journalists in 2002. On the other hand, if one defines autonomy in terms of "almost complete" or a "great deal" of freedom, at least in terms of story selection, the numbers are more complex, and environment reporters generally seem to be saying they have more autonomy than U.S. journalists in general.

The environment reporters and U.S. journalists in general shared preferences in the newspapers and magazines they read and the amount of time they spent watching television news. The top four newspapers were the same for both groups and reflected the national orientation of all four papers.

Reporters who choose to cover specialized stories like the environment might be expected to report higher levels of job satisfaction than U.S. journalists in general. While this study found high levels of job satisfaction among environment reporters, the levels were similar to those found for U.S. journalists.

Overall, the dominant finding of this study is that environment reporters working at daily newspapers and television stations share many individual and work-related characteristics with U.S. journalists in general. Environment reporters are journalists first, perhaps due in part to their similar backgrounds and to the basic professional training received by most journalists. The differences that exist between some environment reporters and U.S. journalists in general may be related to differences that do exist in their college education.

Data from this national study may lay the foundation for basic theory building. The authors propose a uniform theory of journalism education that argues that journalists are journalists first because of the similarities in their studies, training, and experience and that differences among reporters may be related to variations in their education or factors that affect their choice of study. Such a theory of journalism education provides an explanation for the 
similarities that exist among American journalists regardless of their age, ethnicity, gender, or politics and for the differences that exist as well. A uniform theory of journalism education may also provide an explanation for the general conflicts that exist between reporters and their sources, whose education and training differ.

In addition, the findings in this study that newspapers employ more specialized reporters than do television stations, and that the bigger the newspaper, the more specialists, suggest that bigger is better for specialized reporting. This bigger is better theory of specialized reporting does not always appear to be true, given some reported regional differences, but the impact of size on specialty beats appears often enough to be worth pursuing, especially at a time when the fate of some of the nation's larger newspapers is under threat by corporate readjustments. If bigger really is better, then perhaps big newspapers should be sustained, despite the cost of operation. 


\section{References}

Atwater, T., Salwen, M., \& Anderson R. B. (1985). Media agenda setting with environment issues. Journalism Quarterly, 62, 393-97.

Blum, D., Knudson, M., \& Henig, R. M. (Eds.). (2006). A field guide for science writers (3rd ed.). New York: Oxford University Press.

Cantrill, J. G. (1993). Communication and our environment: Categorizing research in environmental advocacy. Journal of Applied Communication Research, 21, 14-15, 66-95.

Cohn, V. (1990). Reporting on risk. Washington, DC: Media Institute.

Friedman, S. M. (1990). Two decades of the environmental beat. Gannett Center Journal, 4, 17.

Friedman, S. M. (2003, August 1). The third decade of environmental journalism: A qualitative review. Paper presented at Association for Education in Journalism and Mass Communication conference, Kansas City, MO.

Greenberg, M. R., Sandman, P. M., Sachsman, D. B., \& Salomone, K. L. (1989, March). Network television news coverage of environmental risks. Environment, 31, 16-20, 4044.

Hansen, A., (Ed.). (1993). The mass media and environmental issues. London: Leicester University Press.

Hotz, R. L. (2006). Large newspapers. In D. B. Blum, M. Knudson, and R. M. Henig (Eds.) A Field Guide for Science Writers (pp. 55-61). New York: Oxford University Press.

Johnstone, J. W. C., Slawski, E. J., \& Bowman, W. W. (1976). The News People: A Sociological Portrait of American Journalists and Their Work. Urbana: University of Illinois Press.

Krieghbaum, H. (1940). The background and training of science writers. Journalism Quarterly, $17,15-18$. 
Lacy, S., \& Coulson, D.C. (2000). Comparative case study: Newspaper source use on the environmental beat. Newspaper Research Journal, 21(winter), 13-25.

Morris, B. R. (1999). Are journalists qualified to write about health and science? Journal of the Mississippi Academy of Sciences, 44(4), 183-189.

Rogers, P. (2002). Complexity in environment reporting is critical to public decision making: '...the craft is now firmly entrenched as a key beat in American journalism.' Nieman Reports, 56(winter), 32.

Sachsman, D. B. (1973). Public relations influence on environmental coverage (in the San Francisco Bay area) (Doctoral dissertation, Department of Communication, Stanford University, Stanford, CA, 1973).

Sachsman, D. B. (1976). Public relations influence on coverage of environment in San Francisco area. Journalism Quarterly, 53(spring), 54-60.

Sachsman, D. B. (1985). Linking the scientist and the journalist. In Richard A. Young (Ed.) HazPro '85 (pp. 196-202). Northbrook, IL: Pudvan Publishing Company.

Sachsman, D. B. (1996). The mass media “discover" the environment: Influences on environmental reporting in the first twenty years. In J. G. Cantrill and C. L. Oravec (Eds.), The symbolic earth: Discourse and our creation of the environment (pp. 241-256). Lexington, KY: The University Press of Kentucky.

Smith, C. (1993). News sources and power elites in coverage of the Exxon Valdez oil spill. Journalism Quarterly, 70(summer), 393-402.

Storad, C. J. (1984). Who are the metropolitan daily newspaper science journalists, and how do they work? Newspaper Research Journal, 6, 39-48. 
Taylor, C. E., Lee, J., \& Davie, W. R. (2000). Local press coverage of environmental conflict. Journalism and Mass Communication Quarterly, 77(spring), 175-92.

Valenti, J. M. (1995). Ethical decision making in environmental communication. Journal of Mass Media Ethics, 13, 219-31.

Valenti, J. M. (1998). Reporting hantavirus: The impact of cultural diversity in environmental and health news. In Y. R. Kamalipour and T. Carilli (Eds.), Cultural diversity and the U.S. media (pp. 231-244). New York: SUNY Press.

Valenti, J. M. (1999). Commentary: How well do scientists communicate to media? Science Communication, 21, 172-78.

Valenti, J. M. (2000a). A review of the President's Council on Sustainable Development (U.S.): Building networks, throwing pebbles at a Goliath media. In W. L. Filho (Ed.), Communicating sustainability (pp.121-133). Bern: Peter Lan Scientific Publishers.

Valenti, J. M. (2000b). Improving the scientist/journalists conversation. Science and Engineering Ethics, 6, 543-48.

Ward, B. (2001). The environment beat bounces back. SEJournal, 11(spring), 1, 12-14.

Weaver, D. H., Beam, R. A., Brownlee, B. J., Voakes, P. S., \& Wilhoit, G. C. (2007). The American journalist in the $21^{\text {st }}$ century: U.S. newspeople at the dawn of a new millennium. Mahwah, NJ: Lawrence Erlbaum.

Weaver, D. H., \& Wilhoit, G. C. (1986). The American journalist: A portrait of U.S. newspeople and their work. Bloomington: Indiana University Press.

Weaver, D.H., \& Wilhoit, G. C. (1996). The American journalist in the 1990s: U.S. newspeople at the end of an era. Mahwah, NJ: Lawrence Erlbaum. 
Table 1. News organizations with environment reporters*

\begin{tabular}{|c|c|c|c|c|c|c|c|}
\hline & \multicolumn{3}{|c|}{ Newspapers } & \multicolumn{4}{|c|}{ Television Stations } \\
\hline & \multirow{5}{*}{$\begin{array}{l}\text { Total } \\
\text { Daily } \\
\text { News- } \\
\text { papers }\end{array}$} & \multirow{5}{*}{$\begin{array}{l}\text { Newspapers with } \\
\text { Environment Reporters }\end{array}$} & \multirow{5}{*}{$\begin{array}{l}\% \text { Papers } \\
\text { with Env. } \\
\text { Reporters }\end{array}$} & $\overline{\mathrm{TV}}$ & \multirow{5}{*}{\multicolumn{2}{|c|}{$\begin{array}{l}\text { TV Stations } \\
\text { with } \\
\text { Environment } \\
\text { Reporters }\end{array}$}} & \multirow{5}{*}{$\begin{array}{l}\% \text { Stations } \\
\text { with Env. } \\
\text { Reporters }\end{array}$} \\
\hline & & & & Stations & & & \\
\hline & & & & with & & & \\
\hline & & & & News & & & \\
\hline & & & & Directors & & & \\
\hline Region & \multicolumn{3}{|c|}{ Papers/Reporters } & \multicolumn{4}{|c|}{$\underline{\text { Stations/Reporters }}$} \\
\hline New England & 82 & $42^{* * *}$ with 51 & $51.2 \%$ & 33 & 4 with & 4 & $12.1 \%$ \\
\hline Mountain West & 110 & 55 with 81 & $50.0 \%$ & 81 & 10 with & 10 & $12.3 \%$ \\
\hline South & 310 & 124 with 131 & $40.0 \%$ & 194 & $23^{* *}$ with & 27 & $11.9 \%$ \\
\hline Pacific West & 147 & $93^{* * *}$ with 114 & $63.3 \%$ & 96 & $15^{* *}$ with & 13 & $15.6 \%$ \\
\hline Mid Atlantic & 169 & $48^{* * *}$ with 53 & $28.4 \%$ & 89 & 0 with & 0 & $0.0 \%$ \\
\hline Mid Central & 310 & 101 with 103 & $32.6 \%$ & 138 & $15^{* *}$ with & 14 & $10.9 \%$ \\
\hline West Central & 334 & $71^{* *}$ with $70^{* * * *}$ & $\underline{21.3 \%}$ & $\underline{228}$ & $\underline{19^{* *} \text { with }}$ & 15 & $8.3 \%$ \\
\hline Total & 1,462 & 534 with 603 & $36.5 \%$ & 859 & with & 83 & $10.0 \%$ \\
\hline
\end{tabular}

Question: Do you cover the environment on a regular basis as part of your reporting duties?

* The number of news organizations with environment reporters differs from the number of environment reporters because some news organizations have more than one environment reporter, while others share an environment reporter.

*** In New England, two newspapers shared one reporter; in the Pacific West, four papers shared one, three shared one, and three shared one. In the Mid Atlantic states, two papers shared one, while in the West Central region, four interrelated newspapers employed a total of three reporters (with one reporter's work being published in four papers, one reporter's work being published in two papers, and the third reporter's work being published in only one paper). In the South, two television stations each had two reporters and one station had four, while two stations shared one reporter; in the Pacific West, three stations shared one reporter; in the Mid Central, two stations shared one; and in the West Central four stations shared one and two stations shared one.

**** One newspaper had an environment reporter who was previously counted and interviewed when he worked in a different region. The reporter's interview was counted only once while both newspapers were given credit for the presence of an environment reporter. 
Table 2. Newspapers with environment reporters by circulation

\begin{tabular}{|c|c|c|c|c|c|c|c|}
\hline $\begin{array}{l}\text { Number of } \\
\text { Environment }\end{array}$ & Less than & $14,000-$ & $30,000-$ & More than & Total & Total & Interviewed \\
\hline Reporters & 14,000 & 29,999 & 59,999 & 60,000 & Newspapers & Reporters & Reporters \\
\hline 0 & 613 & 210 & 66 & 39 & 928 & - & - \\
\hline 1 & 149 & 119 & 96 & 112 & 476 & $466.25 * \dagger$ & $445.25^{*}$ \\
\hline 2 & 6 & 11 & 5 & 20 & 42 & $78.75 *$ & $77.75^{*}$ \\
\hline 3 & 1 & 0 & 2 & 6 & 9 & 27 & 25 \\
\hline 4 & 0 & 0 & 0 & 4 & 4 & 16 & 16 \\
\hline 5 & 0 & 0 & 1 & 2 & 3 & 15 & 13 \\
\hline Total & 769 & 340 & 170 & 183 & 1,462 & 603 & 577 \\
\hline
\end{tabular}

Total of 534 out of $1,462(36.5 \%)$ newspapers had 603 reporters

*The reason the number of reporters is given in fractions is because some newspapers shared environment reporters. If two newspapers shared one environment reporter, the reporter was split .50 and .50 . The sharing of environment reporters also accounts for the fact that there were fewer total reporters than there were newspapers with one environment reporter and the fact that the number of environment reporters at newspapers with two environment reporters does not add up to double the number of those newspapers.

$\dagger$ One newspaper had an environment reporter who was previously counted and interviewed when he worked in a different region. The reporter was counted only once while both newspapers were given credit for the presence of an environment reporter. 
Environment reporters and U.S. journalists 28

Table 3. Job titles of "environment reporters"

\begin{tabular}{|c|c|c|c|c|c|c|c|c|}
\hline Job Titles & $\begin{array}{c}\text { New } \\
\text { England } \\
(2000)\end{array}$ & $\begin{array}{l}\text { Mountain } \\
\text { West } \\
(2001)\end{array}$ & $\begin{array}{l}\text { South } \\
(2002- \\
2003)\end{array}$ & $\begin{array}{c}\text { Pacific } \\
\text { West } \\
(2002, \\
2004-2005)\end{array}$ & $\begin{array}{c}\text { Mid } \\
\text { Atlantic } \\
(2003- \\
2004)\end{array}$ & $\begin{array}{c}\text { Mid } \\
\text { Central } \\
(2004- \\
2005)\end{array}$ & $\begin{array}{c}\text { West } \\
\text { Central } \\
(2004- \\
2005)\end{array}$ & $\begin{array}{l}\text { National } \\
(2000- \\
2005)\end{array}$ \\
\hline \multicolumn{9}{|l|}{ Environment } \\
\hline Reporter, Writer; & 10 & 28 & 60 & 29 & 16 & 24 & 21 & 188 \\
\hline $\begin{array}{l}\text { All Environment } \\
\text { Combos }\end{array}$ & $18.2 \%$ & $30.8 \%$ & $39.7 \%$ & $25.4 \%$ & $31.4 \%$ & $23.8 \%$ & $24.7 \%$ & $29.0 \%$ \\
\hline \multicolumn{9}{|l|}{ All Natural } \\
\hline Resources, & 0 & 8 & 13 & 9 & 1 & 2 & 3 & 36 \\
\hline $\begin{array}{l}\text { Agricultural, } \\
\text { Outdoor Except }\end{array}$ & $0 \%$ & $8.8 \%$ & $8.6 \%$ & $7.9 \%$ & $2.0 \%$ & $2.0 \%$ & $3.5 \%$ & $5.6 \%$ \\
\hline Environment & & & & & & & & \\
\hline All Science Except & 5 & 1 & 2 & 2 & 0 & 1 & 1 & 12 \\
\hline Environment & $9.1 \%$ & $1.1 \%$ & $1.3 \%$ & $1.8 \%$ & $0.0 \%$ & $1.0 \%$ & $1.2 \%$ & $1.9 \%$ \\
\hline All Health Except & 2 & 0 & 0 & 1 & 1 & 0 & 1 & 5 \\
\hline Environment & $3.6 \%$ & $0.0 \%$ & $0.0 \%$ & $0.9 \%$ & $2.0 \%$ & $0.0 \%$ & $1.2 \%$ & $0.8 \%$ \\
\hline $\begin{array}{l}\text { Reporter, General } \\
\text { Assignment, Staff }\end{array}$ & 30 & 45 & 74 & 55 & 29 & 51 & 36 & 320 \\
\hline Writer & $54.5 \%$ & $49.5 \%$ & $49.0 \%$ & $48.2 \%$ & $56.9 \%$ & $50.5 \%$ & $42.4 \%$ & $49.4 \%$ \\
\hline Specialized & & & & & & & & \\
\hline Reporters - & 6 & 5 & 0 & 9 & 3 & 1 & 0 & 24 \\
\hline $\begin{array}{l}\text { Business, Politics, } \\
\text { Sports }\end{array}$ & $10.9 \%$ & $5.5 \%$ & $0.0 \%$ & $7.9 \%$ & $5.9 \%$ & $1.0 \%$ & $0.0 \%$ & $3.7 \%$ \\
\hline Specialized Editor, & & & & & & & & \\
\hline Manager - City & 2 & 4 & 2 & 9 & 1 & 22 & 23 & 63 \\
\hline $\begin{array}{l}\text { Editor, Assignment } \\
\text { Editor }\end{array}$ & $3.6 \%$ & $4.4 \%$ & $1.3 \%$ & $7.9 \%$ & $2.0 \%$ & $21.8 \%$ & $27.1 \%$ & $9.7 \%$ \\
\hline Total & $\begin{array}{c}55 \\
100.0 \%\end{array}$ & $\begin{array}{c}91 \\
100.0 \%\end{array}$ & $\begin{array}{l}151 \\
100.0 \%\end{array}$ & $\begin{array}{l}114 * \\
100.0 \%\end{array}$ & $\begin{array}{c}51^{*} \\
100.0 \%\end{array}$ & $\begin{array}{l}101 \\
100.0 \%\end{array}$ & $\begin{array}{c}85 \\
100.0 \%\end{array}$ & $\begin{array}{l}648 * \\
100.0 \%\end{array}$ \\
\hline
\end{tabular}

Question: What is your exact job title at (Name of Organization)?

* The total $N$ may vary due to some participants not answering the question. 
Environment reporters and U.S. journalists 29

Table 4. Percentage of time spent covering "environment" stories

\begin{tabular}{|c|c|c|c|c|c|c|}
\hline Region & $0-33 \%$ & $34-66 \%$ & $67-100 \%$ & Total & $\mathrm{n}$ & mean* \\
\hline New England (2000) & $58.2 \%$ & $23.6 \%$ & $18.2 \%$ & $100 \%$ & 55 & $37.9 \%$ \\
\hline Mountain West (2001) & $37.4 \%$ & $31.9 \%$ & $30.7 \%$ & $100 \%$ & 91 & $50.0 \%$ \\
\hline South (2002-03) & $51.7 \%$ & $18.5 \%$ & $29.8 \%$ & $100 \%$ & 151 & $44.2 \%$ \\
\hline Pacific West (2002, & $35.3 \%$ & $23.3 \%$ & $41.4 \%$ & $100 \%$ & 116 & $54.8 \%$ \\
\hline \multicolumn{7}{|l|}{ 2004-05) } \\
\hline Mid Atlantic (2003-04) & $49.1 \%$ & $17.0 \%$ & $33.9 \%$ & $100 \%$ & 53 & $47.4 \%$ \\
\hline Mid Central (2004-05) & $69.3 \%$ & $15.8 \%$ & $14.9 \%$ & $100 \%$ & 101 & $30.2 \%$ \\
\hline West Central (2004-05) & $\underline{64.7 \%}$ & $\underline{22.4 \%}$ & $12.9 \%$ & $100 \%$ & $\underline{85}$ & $\underline{33.0 \%}$ \\
\hline Total & $52.2 \%$ & $21.8 \%$ & $26.0 \%$ & $100 \%$ & 652 & $43.0 \%$ \\
\hline
\end{tabular}


Environment reporters and U.S. journalists 30

Table 5. Personal characteristics of environment reporters vs. U.S. journalists

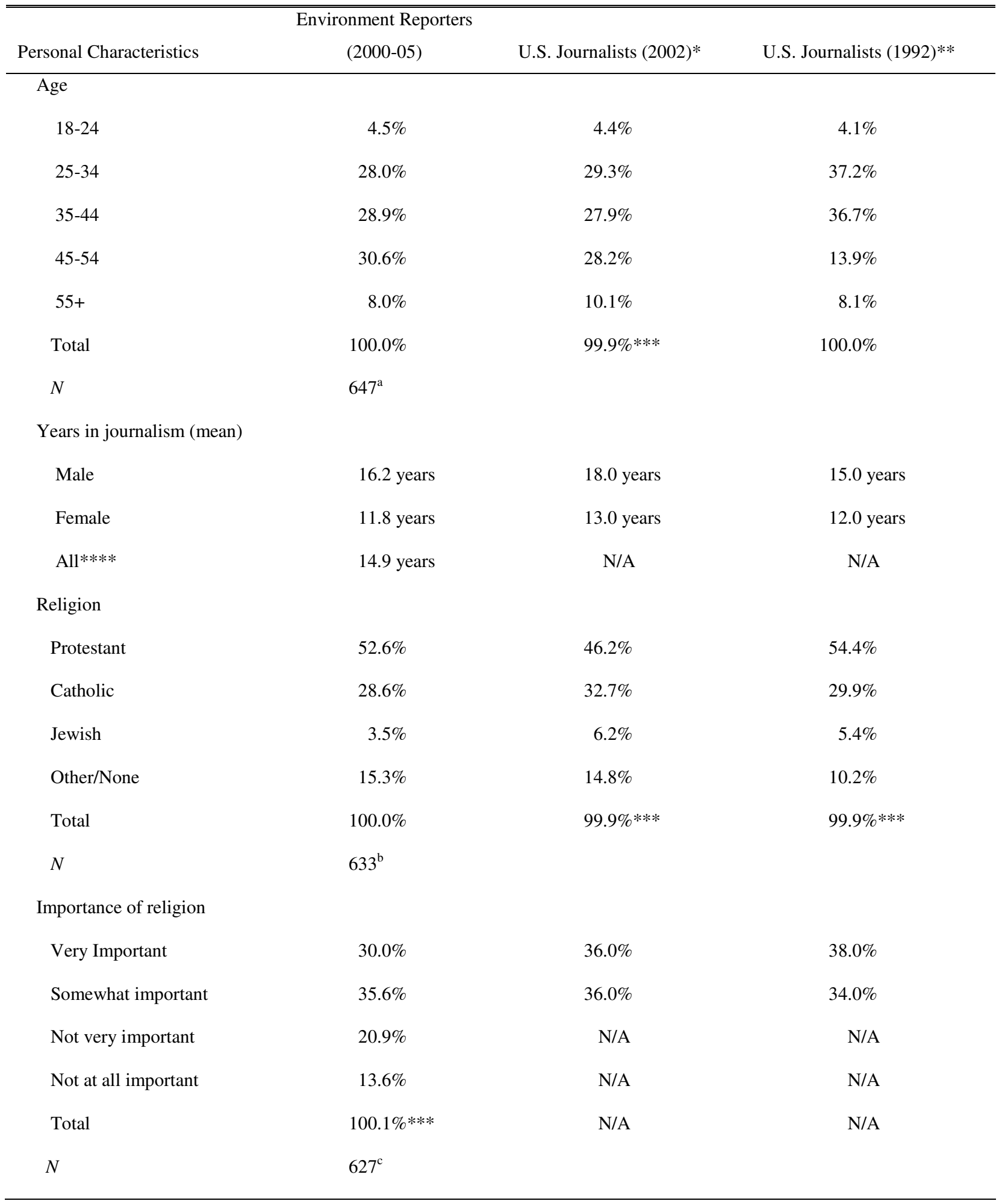


Environment reporters and U.S. journalists 31

\begin{tabular}{|c|c|c|c|}
\hline \multicolumn{4}{|l|}{ Ethnicity } \\
\hline White/Other & $96.6 \%$ & $91.6 \%$ & $92.5 \%$ \\
\hline African American & $0.9 \%$ & $3.7 \%$ & $3.7 \%$ \\
\hline Hispanic & $1.4 \%$ & $3.3 \%$ & $2.2 \%$ \\
\hline Asian & $0.8 \%$ & $1.0 \%$ & $1.0 \%$ \\
\hline Native American & $0.3 \%$ & $0.4 \%$ & $0.6 \%$ \\
\hline Total & $100.0 \%$ & $100.0 \%$ & $100.0 \%$ \\
\hline$N$ & $640^{\mathrm{d}}$ & & \\
\hline \multicolumn{4}{|l|}{ Gender } \\
\hline Male & $70.7 \%$ & $67.0 \%$ & $66.0 \%$ \\
\hline Female & $29.3 \%$ & $33.0 \%$ & $34.0 \%$ \\
\hline Total & $100.0 \%$ & $100.0 \%$ & $100.0 \%$ \\
\hline$N$ & $648^{\mathrm{e}}$ & & \\
\hline \multicolumn{4}{|l|}{ Political Affiliation } \\
\hline Democrat & $32.6 \%$ & $35.9 \%$ & $44.1 \%$ \\
\hline Republican & $9.3 \%$ & $18.0 \%$ & $16.4 \%$ \\
\hline Independent & $51.8 \%$ & $32.5 \%$ & $34.4 \%$ \\
\hline Other & $6.3 \%$ & $13.6 \%$ & $5.1 \%$ \\
\hline Total & $100.0 \%$ & $100.0 \%$ & $100.0 \%$ \\
\hline$N$ & $604^{\mathrm{f}}$ & & \\
\hline \multicolumn{4}{|l|}{ Income } \\
\hline Less than $\$ 35,000$ & $47.8 \%$ & N/A & N/A \\
\hline$\$ 35,000$ to $\$ 60,000$ & $40.2 \%$ & N/A & N/A \\
\hline More than $\$ 60,000$ & $12.0 \%$ & N/A & N/A \\
\hline Total & $100.0 \%$ & N/A & N/A \\
\hline$N$ & $609^{g}$ & & \\
\hline
\end{tabular}

(Results reported in percentage unless otherwise noted)

U.S. journalists' median income in 2002, \$43,588

* Weaver et al. (2007), pp. 6-22, and 97-99. “The maximum sampling error at the $95 \%$ level of confidence for this main probability sample is plus or minus 3 percentage points,” pp. 259. 


\section{Environment reporters and U.S. journalists 32}

** Weaver and Wilhoit (1996), pp. 6-21 and 92-96. "The sampling error margin at the 95\% level of confidence for this main probability sample of 1,156 was plus or minus three percentage points," pp. 251.

*** Totals do not equal $100 \%$ due to rounding.

*** Mean computed against ungrouped "years in journalism" variable.

${ }^{a}$ Total does not include reporters who responded no answer (5).

${ }^{\mathrm{b}}$ Total does not include reporters who responded no answer (6) or refused to answer (13).

${ }^{\mathrm{c}}$ Total does not include reporters who responded don't know (2), no answer (6), or refused to answer (17).

${ }^{\mathrm{d}}$ Total does not include reporters who responded no answer (5) or refused to answer (7).

${ }^{\mathrm{e}}$ Total does not include reporters who responded no answer (3) or refused to answer (1).

${ }^{\mathrm{f}}$ Total does not include reporters who responded don't know (3), no answer (12), or refused to answer (33).

g Total does not include reporters who responded don't know (4), no answer (20), or refused to answer (19). 
Environment reporters and U.S. journalists 33

Table 6. Educational characteristics of environment reporters vs. U.S. journalists

\begin{tabular}{|c|c|c|c|}
\hline Personal Characteristics & $\begin{array}{l}\text { Environment Reporters } \\
\text { (2000-05) }\end{array}$ & $\begin{array}{l}\text { U.S. Journalists } \\
\qquad(2002)^{*}\end{array}$ & $\begin{array}{l}\text { U.S. Journalists } \\
\text { (1992)** }\end{array}$ \\
\hline \multicolumn{4}{|l|}{ 1. Level of school completed } \\
\hline H.S. or less & $0.6 \%$ & $1.8 \%$ & $4.3 \%$ \\
\hline Some college & $6.2 \%$ & $8.9 \%$ & $13.6 \%$ \\
\hline College graduate & $68.1 \%$ & $68.0 \%$ & $64.5 \%$ \\
\hline Some graduate training & $7.6 \%$ & $4.7 \%$ & $6.2 \%$ \\
\hline Master's degree or more & $17.6 \%$ & $16.6 \%$ & $11.4 \%$ \\
\hline Total & $100.1 \% * * *$ & $100.0 \%$ & $100.0 \%$ \\
\hline$N$ & $648^{\mathrm{a}}$ & 1148 & 1147 \\
\hline \multicolumn{4}{|l|}{ 2. Undergraduate majors } \\
\hline \multicolumn{4}{|l|}{ (of college graduates) } \\
\hline Journalism/Communication & $44.9 \%$ & $57.7 \%$ & $56.3 \%$ \\
\hline Journalism/Communication & $5.1 \%$ & & \\
\hline \multicolumn{4}{|l|}{ plus another field } \\
\hline Subtotal: Journalism + Comm. & $50.0 \%$ & $57.7 \%$ & $56.3 \%$ \\
\hline Science & $23.3 \%$ & $2.9 \% * * * *$ & $2.2 \% * * * *$ \\
\hline All other fields & $25.7 \%$ & $39.2 \%$ & $41.4 \%$ \\
\hline No major & $1.0 \%$ & N/A & N/A \\
\hline Total & $100.0 \%$ & $99.8 \%$ & $99.9 \%$ \\
\hline$N$ & $572^{\mathrm{b}}$ & N/A & N/A \\
\hline \multicolumn{4}{|l|}{ 3. Undergraduate minor } \\
\hline \multicolumn{4}{|l|}{ (of college graduates) } \\
\hline Journalism/Communication & $4.4 \%$ & N/A & N/A \\
\hline Science & $38.7 \%$ & N/A & N/A \\
\hline Other & $14.9 \%$ & N/A & N/A \\
\hline No minor & $41.9 \%$ & N/A & N/A \\
\hline Total $* * *$ & $99.9 \%$ & N/A & N/A \\
\hline$N$ & $542^{\mathrm{c}}$ & N/A & N/A \\
\hline
\end{tabular}


Environment reporters and U.S. journalists 34

$\begin{array}{lc}\text { Journalism/Communication } & 50.6 \% \\ \text { Science } & 18.4 \% \\ \text { Ph.D./law/MD } & 3.4 \% \\ \text { Other } & 27.6 \% \\ \text { Total } & 100.0 \% \\ N & 87(\text { of } 114)^{\mathrm{d}}\end{array}$

$\begin{array}{ll}\text { N/A } & \text { N/A } \\ \text { N/A } & \text { N/A } \\ \text { N/A } & \text { N/A } \\ \text { N/A } & \text { N/A } \\ \text { N/A } & \text { N/A } \\ \text { N/A } & \text { N/A }\end{array}$

5. Have you had short courses, sabbaticals, workshops since becoming a journalist? (\% yes shown)

6. Do you feel you need additional training in journalism or other subjects? (\% yes shown)

What area:

Natural science
Environment
Journalism/Communication
Computers/new
technology/multimedia
English, literature, writing
Law
Political science/government
Business
Economics
History
Photography
Modern languages
News analysis, clinics, seminars
Shorthand
Seneral (e.g. "any course," "all
Spectific answers not otherwise

$13.3 \% \quad(87)$

$9.7 \% \quad(63)$

$9.7 \% \quad(63)$

$3.8 \%$

$3.2 \%$

$1.5 \% \quad(10)$

$1.4 \% \quad(9)$

$1.1 \% \quad(7)$

$1.1 \% \quad(7)$

$0.9 \% \quad(6)$

$0.3 \%$

$0.3 \%$

(2)

$0.2 \% \quad(1)$

$0.0 \%$

(0)

$4.4 \%$

$4.0 \%$

(26)
N/A N/A

N/A N/A

$34.2 \% \quad 11.4 \%$

$12.4 \% \quad$ N/A

$<1.5 \% \quad 4.7 \%$

$5.2 \% \quad 2.2 \%$

$2.1 \% \quad 4.9 \%$

$2.1 \% \quad 7.2 \%$

$\begin{array}{ll}<1.5 \% & 2.9 \%\end{array}$

$\begin{array}{ll}<1.5 \% & 3.8 \%\end{array}$

$4.1 \% \quad 1.6 \%$

$6.2 \% \quad 2.6 \%$

$8.2 \% \quad 9.8 \%$

$\begin{array}{ll}<1.5 \% & 0.3 \%\end{array}$

NA NA

NA 


\section{Environment reporters and U.S. journalists 35}

$\begin{array}{llcr}\text { listed (e.g. philosophy) } & & & \text { NA } \\ \text { No Answer; non-responsive } & 21.8 \%(142) & \text { NA } & \text { NA } \\ \text { Not seeking additional training } & 23.3 \%(152) & 23.0 \% & 38.4 \% \\ \text { Total } & 100.0 \% & 100.0 \% \dagger \dagger & 100.0 \% \\ N & 652 & 1149 & 1148\end{array}$

Question: What is the highest grade of school, or level of education, you have completed? (Ask open ended; circle best category); 1) no school or kindergarten, 2) grades 1-11,3) completed high school, 4) 1-3 years of college,

5) graduated from college, 6) some graduate work, no degree, 7) master's degree, 8) doctorate, law or medical degree, 9) vocational or technical school beyond.

Question: What was your undergraduate major? 1) Journalism, 2) Journalism and other major (Specify Other )

3) Other major(s) - What was it? (Specify Other____ ) 4) Did not have a major...

Question: What was your undergraduate minor, if any? 1) Journalism, 2) Journalism and other minor (Specify

Other ), 3) Other minor(s) - What was it? (Specify Other ), 4) Did not have a minor...

Question: What field were you in graduate or professional school? Field

Question: Have you had any short courses, sabbaticals, workshops or fellowships since becoming a journalist?

1) Yes, 2) No

Question: Do you feel you need additional training in journalism or other subjects? 1) Yes, 2) No

* Weaver et al. (2007), pp. 31-53.

** Weaver and Wilhoit (1996), pp. 29-47.

*** Totals do not equal $100 \%$ due to rounding

**** The figures for Science majors among U.S. journalists in 2002 include $2.8 \%$ "physical and biological sciences" plus $0.1 \%$ “agriculture" and for 1992, 2.1\% "physical and biological sciences" plus $0.1 \%$ "agriculture."

$\dagger$ In cases of multiple responses and multiple-word responses (e.g., environmental journalism), first response or first word coded.

$\dagger \dagger$ In Weaver et al. (2007), subjects mentioned by fewer than $1.5 \%$ of the respondents are listed here as $<1.5 \%$. Weaver et al. (2007) lists the total percentage as $100 \%$.

${ }^{a}$ Total does not include reporters who responded no answer (3) or refused to answer (1).

b Total does not include reporters who responded don't know (1), no answer (22), or refused to answer (13), and the 44 who either did not attend or did not graduate from college.

${ }^{\mathrm{c}}$ Total does not include reporters who responded don't know (13), no answer (52), or refused to answer (1), and the 44 who either did not attend or did not graduate from college. 
Environment reporters and U.S. journalists 36

${ }^{\mathrm{d}}$ Of the 114 reporters who said they held master's or other advanced degrees, the total reported does not include those who responded no answer (27). 
Environment reporters and U.S. journalists 37

Table 7. Job characteristics of environment reporters vs. U.S. journalists: autonomy in the newsroom

\begin{tabular}{|c|c|c|c|}
\hline Job Characteristics & $\begin{array}{l}\text { Environment Reporters } \\
\text { (2000-05) }\end{array}$ & $\begin{array}{l}\text { U.S. Journalists } \\
\qquad(2002)^{*}\end{array}$ & $\begin{array}{l}\text { U.S Journalists } \\
\text { (1992)** }\end{array}$ \\
\hline \multicolumn{4}{|c|}{ They are almost always able to get a } \\
\hline \multicolumn{4}{|c|}{ story covered that they think should } \\
\hline \multicolumn{4}{|l|}{ be covered } \\
\hline Almost complete & $36.1 \%$ & $52.0 \%$ & $55.0 \%$ \\
\hline Great deal & $45.6 \%$ & N/A & N/A \\
\hline Some & $16.4 \%$ & N/A & N/A \\
\hline Not much & $1.8 \%$ & N/A & N/A \\
\hline Not at all & $0.0 \%$ & N/A & N/A \\
\hline Total & $99.9 \% * * *$ & N/A & N/A \\
\hline \multicolumn{4}{|c|}{ They have almost complete freedom } \\
\hline \multicolumn{4}{|c|}{ in selecting the stories they work on } \\
\hline Almost complete & $33.1 \%$ & $40.0 \%$ & $44.0 \%$ \\
\hline Great deal & $53.2 \%$ & N/A & N/A \\
\hline Some & $12.5 \%$ & N/A & N/A \\
\hline Not much & $1.1 \%$ & N/A & N/A \\
\hline Not at all & $0.2 \%$ & N/A & N/A \\
\hline Total & $100.1 \% * * *$ & N/A & N/A \\
\hline \multicolumn{4}{|c|}{ They have almost complete freedom in } \\
\hline \multicolumn{4}{|c|}{ deciding which aspects of a news story } \\
\hline \multicolumn{4}{|l|}{ should be emphasized } \\
\hline Almost complete & $38.2 \%$ & $42.0 \%$ & $51.0 \%$ \\
\hline Great deal & $50.5 \%$ & N/A & N/A \\
\hline Some & $10.8 \%$ & N/A & N/A \\
\hline Not much & $0.6 \%$ & N/A & N/A \\
\hline Not at all & $0.0 \%$ & N/A & N/A \\
\hline Total & $100.1 \% * * *$ & N/A & N/A \\
\hline
\end{tabular}


Environment reporters and U.S. journalists 38

The amount of editing your stories gets

from others at your organization

$3.1 \%$

N/A

N/A

Considerable amount

$11.7 \%$

N/A

N/A

Some

$44.8 \%$

N/A

N/A

Little

$36.9 \%$

N/A

N/A

None at all

$3.4 \%$

$16.0 \%$

$23.0 \%$

Total

$99.9 \% * * *$

N/A

N/A

*Weaver et al. (2007), pp. 73-75.

**Weaver and Wilhoit (1996), pp. 62-65.

***Totals do not equal $100 \%$ due to rounding 
Environment reporters and U.S. journalists 39

Table 8. Amount of freedom men and women had in being able to select stories

\begin{tabular}{|c|c|c|c|c|c|c|c|c|}
\hline & \multicolumn{4}{|c|}{ Environment Reporters (2000-05) } & \multicolumn{4}{|c|}{ U.S. Journalists (2002)* } \\
\hline & \multicolumn{2}{|c|}{$\underline{\text { Print }}$} & \multicolumn{2}{|c|}{$\underline{\text { Broadcast }}$} & \multicolumn{2}{|c|}{$\underline{\text { Print }}$} & \multicolumn{2}{|c|}{$\underline{\text { Broadcast }}$} \\
\hline selecting the stories & Men & Women & Men & Women & Men & Women & Men & Women \\
\hline they work on: & $n=399$ & $n=173$ & $n=58$ & $n=16$ & $n=580$ & $n=291$ & $n=184$ & $n=84$ \\
\hline Almost complete & $31.8 \%$ & $35.3 \%$ & $41.4 \%$ & $12.5 \%$ & $35.0 \%$ & $39.9 \%$ & $39.7 \%$ & $31.0 \%$ \\
\hline Great deal & $56.1 \%$ & $50.9 \%$ & $34.5 \%$ & $68.8 \%$ & $45.2 \%$ & $38.8 \%$ & $41.3 \%$ & $35.7 \%$ \\
\hline Some freedom & $11.3 \%$ & $12.7 \%$ & $20.7 \%$ & $12.5 \%$ & $17.9 \%$ & $16.2 \%$ & $17.4 \%$ & $31.0 \%$ \\
\hline Not much & $0.8 \%$ & $1.2 \%$ & $3.4 \%$ & $0.0 \%$ & $0.0 \%$ & $0.0 \%$ & $0.0 \%$ & $0.0 \%$ \\
\hline None at all & $0.0 \%$ & $0.0 \%$ & $0.0 \%$ & $6.3 \%$ & $1.9 \%$ & $5.2 \%$ & $1.6 \%$ & $2.4 \%$ \\
\hline
\end{tabular}

Question: How much freedom do you usually have in selecting the stories you work on? Would you say...

*Weaver et al. (2007), p. 187. 
Environment reporters and U.S. journalists 40

Table 9. Media usage patterns of environment reporters vs. U.S. journalists

\begin{tabular}{|c|c|c|c|}
\hline \multicolumn{4}{|c|}{ Environment Reporters } \\
\hline Media Usage Patterns & $(2000-05)$ & U.S. Journalists (2002)* & U.S. Journalists (1992)** \\
\hline \multicolumn{4}{|l|}{ Magazines Used } \\
\hline Newsweek & $24.2 \%$ & $31.2 \%$ & $32.2 \%$ \\
\hline Time & $20.6 \%$ & $27.9 \%$ & $28.5 \%$ \\
\hline National Geographic & $15.5 \%$ & N/A & $8.9 \%$ \\
\hline The New Yorker & $15.2 \%$ & $16.1 \%$ & $8.7 \%$ \\
\hline Atlantic Monthly & $8.0 \%$ & $4.3 \%$ & $5.2 \%$ \\
\hline Sports Illustrated & $6.3 \%$ & $16.0 \%$ & $16.5 \%$ \\
\hline U.S. News & $5.5 \%$ & $5.0 \%$ & $9.2 \%$ \\
\hline Harper's & $5.4 \%$ & $3.0 \%$ & $4.2 \%$ \\
\hline Smithsonian & $4.4 \%$ & $2.4 \%$ & $4.4 \%$ \\
\hline Environment Magazine & $4.4 \%$ & N/A & N/A \\
\hline Outside & $3.8 \%$ & N/A & N/A \\
\hline Rolling Stone & $3.4 \%$ & $5.7 \%$ & $6.9 \%$ \\
\hline NY Times Sunday Magazine & $2.6 \%$ & N/A & N/A \\
\hline Columbia Journalism Review & $2.5 \%$ & N/A & N/A \\
\hline The Economist & $2.5 \%$ & $3.7 \%$ & N/A \\
\hline Vanity Fair & $2.3 \%$ & $6.4 \%$ & N/A \\
\hline \multicolumn{4}{|l|}{ Newspapers Used } \\
\hline New York Times & $46.5 \%$ & $38.1 \%$ & $26.1 \%$ \\
\hline Washington Post & $15.3 \%$ & $20.0 \%$ & $11.1 \%$ \\
\hline Wall Street Journal & $14.3 \%$ & $22.9 \%$ & $23.4 \%$ \\
\hline USA Today & $11.8 \%$ & $19.2 \%$ & $21.9 \%$ \\
\hline Los Angeles Times & $9.2 \%$ & $7.4 \%$ & $5.4 \%$ \\
\hline Boston Globe & $4.9 \%$ & $3.5 \%$ & $3.5 \%$ \\
\hline Chicago Tribune & $4.8 \%$ & $7.3 \%$ & $4.6 \%$ \\
\hline San Francisco Chronicle & $3.7 \%$ & $2.2 \%$ & $4.4 \%$ \\
\hline Denver Post & $3.5 \%$ & $2.8 \%$ & $3.0 \%$ \\
\hline
\end{tabular}


Environment reporters and U.S. journalists 41

\begin{tabular}{|c|c|c|c|}
\hline Oregonian & $2.9 \%$ & $1.9 \%$ & N/A \\
\hline Atlanta Journal Constitution & $2.6 \%$ & $3.9 \%$ & $2.7 \%$ \\
\hline Dallas Morning News & $2.3 \%$ & $2.7 \%$ & $2.2 \%$ \\
\hline Rocky Mountain News & $2.0 \%$ & $2.0 \%$ & $2.0 \%$ \\
\hline Hartford Courant & $1.5 \%$ & N/A & $1.5 \%$ \\
\hline Chicago Sun Times & $1.2 \%$ & $2.1 \%$ & $1.4 \%$ \\
\hline \multicolumn{4}{|l|}{ of days watching network news } \\
\hline 0 & $50.9 \%$ & $40.4 \%$ & $34.0 \%$ \\
\hline 1 & $13.1 \%$ & $13.7 \%$ & $15.5 \%$ \\
\hline 2 & $9.7 \%$ & $12.4 \%$ & $12.1 \%$ \\
\hline 3 & $7.4 \%$ & $11.9 \%$ & $11.6 \%$ \\
\hline 4 & $4.8 \%$ & $4.6 \%$ & $7.3 \%$ \\
\hline 5 & $6.3 \%$ & $10.1 \%$ & $10.3 \%$ \\
\hline 6 & $0.8 \%$ & $2.6 \%$ & $3.3 \%$ \\
\hline 7 & $6.9 \%$ & $4.3 \%$ & $5.8 \%$ \\
\hline \multicolumn{4}{|l|}{ of days watching cable news } \\
\hline 0 & $30.4 \%$ & $16.6 \%$ & N/A \\
\hline 1 & $12.0 \%$ & $10.0 \%$ & N/A \\
\hline 2 & $9.7 \%$ & $9.0 \%$ & N/A \\
\hline 3 & $6.0 \%$ & $11.1 \%$ & N/A \\
\hline 4 & $6.0 \%$ & $7.5 \%$ & N/A \\
\hline 5 & $10.0 \%$ & $18.7 \%$ & N/A \\
\hline 6 & $3.1 \%$ & $3.8 \%$ & N/A \\
\hline 7 & $22.7 \%$ & $23.2 \%$ & N/A \\
\hline
\end{tabular}

*Weaver et al. (2007), pp. 23-29.

**Weaver and Wilhoit (1996), pp. 21-26. 
Environment reporters and U.S. journalists 42

Table 10. Job satisfaction of environment reporters and U.S. journalists in general

\begin{tabular}{|c|c|c|c|}
\hline \multirow{3}{*}{ Job Satisfaction } & \multicolumn{3}{|l|}{ Environment } \\
\hline & Reporters & U.S. Journalists & U.S. Journalists \\
\hline & (2000-05) & $(2002)^{*}$ & $(1992)^{* *}$ \\
\hline \multirow[t]{2}{*}{ Very Satisfied } & 201 & & \\
\hline & $31.2 \%$ & $33.3 \%$ & $27.0 \%$ \\
\hline \multirow[t]{2}{*}{ Satisfied } & 348 & & \\
\hline & $54.0 \%$ & $50.6 \%$ & $50.0 \%$ \\
\hline \multirow[t]{2}{*}{ Fairly Dissatisfied } & 81 & & \\
\hline & $12.6 \%$ & $14.4 \%$ & $20.0 \%$ \\
\hline \multirow[t]{2}{*}{ Very Dissatisfied } & 14 & & \\
\hline & $2.2 \%$ & $1.7 \%$ & $3.0 \%$ \\
\hline \multirow[t]{2}{*}{ Total } & $644 * * *$ & 1149 & 1156 \\
\hline & $100.0 \%$ & $100.0 \%$ & $100.0 \%$ \\
\hline
\end{tabular}

Question: All things considered, how satisfied are you with your present job? Would you say...

* Weaver et al. (2006), pp. 107.

** Weaver and Wilhoit (1996), pp. 100.

*** The total $N$ may vary due to some participants not answering the question. 
Environment reporters and U.S. journalists 43

Table 11. Job satisfaction by individual characteristics of environment reporters

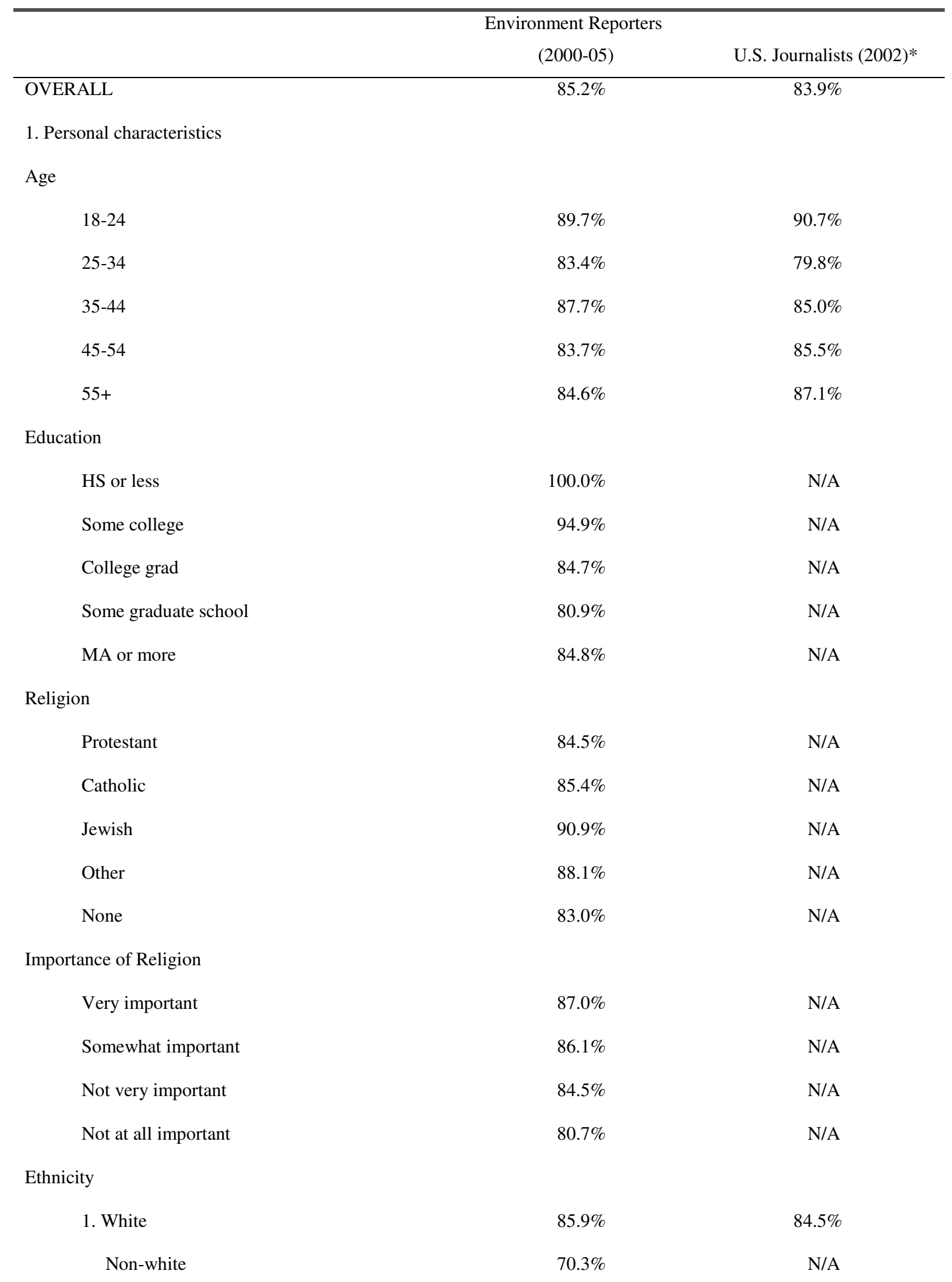


Environment reporters and U.S. journalists 44

2. White

African American

Hispanic

Asian-American

Native American

Gender

Men

Women

Political Affiliation

Democrat

Republican

Independent

Other

Income

Less than $\$ 35,000$

$\$ 35,000$ to $\$ 60,000$

More than $\$ 60,000$

Marital status

Married

Unmarried

2. Job characteristics

Region

New England (2000)

Mountain West (2001)

South (2002-03)

Pacific West (2002, 2004-05)

Mid Atlantic (2003-04)

Mid Central (2004-05)

West Central (2004-05)

Job titles

$\begin{array}{ll}85.9 \% & 84.5 \% \\ 100.0 \% & 77.0 \% \\ 66.7 \% & 78.0 \% \\ 80.0 \% & 80.9 \% \\ 50.0 \% & 89.7 \% * *\end{array}$

$87.1 \%$

$86.6 \%$

$80.4 \%$

$78.7 \%$

$83.2 \%$

N/A

$91.1 \%$

N/A

$85.0 \%$

N/A

$81.6 \%$

N/A

$81.2 \%$

N/A

$90.5 \%$

N/A

$82.2 \%$

N/A

$87.5 \%$

N/A

$82.2 \%$

N/A

$85.5 \%$

N/A

$85.6 \%$

N/A

$86.7 \%$

N/A

$85.3 \%$

N/A

$82.7 \%$

N/A

$85.7 \%$

N/A

$83.1 \%$

N/A 
Environment reporters and U.S. journalists 45

All environment titles

Other titles

Medium

Newspaper reporter

TV reporter

Percent of time covering environment

$1-33 \%$

$34-66 \%$

$67 \%+$

Years in journalism

$1-10$

$11-20$

$21+$

Years covering environment

$1-10$

$11-20$

$21+$

How good a job does your own news organization do in

enhancing the public's understanding of environmental issues?

Outstanding

Very good

Good

Only fair

Poor

How much freedom do you usually have in selecting the stories you work on?

Almost complete freedom

A great deal of freedom

Some freedom

Not much freedom

None at all
$89.8 \%$

N/A

$83.3 \%$

$84.5 \%$

N/A

$90.7 \%$

$83.4 \%$

$82.4 \%$

N/A

$85.0 \%$

N/A

$90.8 \%$

N/A

$84.7 \%$

N/A

$84.3 \%$

N/A

$86.7 \%$

N/A

$87.0 \%$

N/A

$85.0 \%$

N/A

$84.0 \%$

N/A

$95.2 \%$

$95.9 \%$

$90.5 \%$

$89.8 \%$

$86.6 \%$

$77.6 \%$

$72.9 \%$

N/A

$40.0 \%$

N/A

$89.3 \%$

N/A

$89.7 \%$

N/A

$61.7 \%$

N/A

$42.9 \%$

N/A

$0.0 \%$

N/A 


\section{Environment reporters and U.S. journalists 46}

How much freedom do you usually have in deciding which

aspects of a story should be emphasized?

Almost complete freedom

A great deal of freedom

Some freedom

Not much freedom

None at all

If you have a good idea which you think important and should be

followed up, how often are you able to get the subject covered?

Almost complete freedom

A great deal of freedom

Some freedom

Not much freedom

None at all

How much editing do your stories get from others at (your organization)?
A great deal
$80.0 \%$
$89.5 \%$
$87.4 \%$
$82.6 \%$
$76.2 \%$
None at all
A considerable amount
Some
Little somewhat dissatisfied, or 4) very dissatisfied
* Weaver et al. (2007), pp. 108-111 and 190.
** Includes American Indians, Alaska Natives, Pacific Islanders or Others.

$88.7 \%$

$86.9 \%$

$71.4 \%$

$0.0 \%$

$0.0 \%$

$91.4 \%$

$87.3 \%$

$70.8 \%$

$50.0 \%$

$0.0 \%$
N/A

N/A

N/A

N/A

N/A
N/A

N/A

N/A

N/A

N/A

N/A

N/A

N/A

N/A

N/A

Percentages represent those reporters saying they were "very satisfied" or "fairly satisfied" with their jobs

Q: All things considered, how satisfied are you with your present job? Would you say 1) very satisfied, 2) fairly satisfied, 3) 


\section{Endnotes}

${ }^{1}$ The states in New England were Connecticut, Maine, Massachusetts, New Hampshire, Rhode Island, and Vermont; those in the Mountain West were Arizona, Colorado, Idaho, Montana, Nevada, New Mexico, Utah, and Wyoming. Those in the Pacific West were the Pacific Northwestern states of Alaska, Oregon, and Washington, and California and Hawaii; and those in the South were Alabama, Arkansas, Florida, Georgia, Kentucky, Louisiana, Mississippi, North Carolina, South Carolina, Tennessee, and Virginia. The Mid Atlantic region included Delaware, the District of Columbia, Maryland, New Jersey, New York, Pennsylvania; the Mid Central consisted of Illinois, Indiana, Michigan, Ohio, West Virginia, and Wisconsin; while the West Central included Iowa, Kansas, Minnesota, Missouri, Nebraska, North Dakota, Oklahoma, South Dakota, Texas. 